\title{
Identifikasi Gulma di Areal Pertanaman Lada (Piper nigrum L.) di Kampung Sukan Tengah Kecamatan Sambaliung Kabupaten Berau Provinsi Kalimantan Timur
}

\author{
Fatiatul Hasanah $^{1}$, Aditya Murtilaksono ${ }^{2}$ \\ 1,2 Jurusan Agroteknologi Fakultas Pertanian Universitas Borneo Tarakan \\ Jalan Amal Lama Nomor 1 Kelurahan Pantai Amal, Kota Tarakan, 77123 \\ Email: hasanbasrifata@gmail.com
}

Receive: 18 Oktober 2018

Accepted: 9 Oktober 2018

\begin{abstract}
Weeds are plants that can live in the area of cultivation, to determine the type of weed species, identification activities must be carried out. Identification is carried out with the aim to see the diversity of a weed and what weeds are dominant in the pepper planting area (Piper nigrum L.) at Kampung Sukan Tengah, Kecamatan Sambaliung, Kabupaten Berau, Provinsi Kalimantan Timur. This research was conducted in 2017. The research method is by quadratic method, sampling is taken at area of $1 / 2$ ha of pepper planting with a size of $1 \mathrm{~m} \times 1 \mathrm{~m}$ as many as 20 sample plots. After weed samples are obtained, next is identifying weeds and Summed Dominance Ratio. The results of the study identified show there is 16 types of weeds, where there are 5 species of grass weeds, and there are 11 species of broadleaf weeds. The dominant Summed Dominance Ratio value is Ageratum Conizoides sebesar $28.10 \%$.
\end{abstract}

Keywords : Weed, Weed Identification, Squared Method, weed diversity and SDR value

\section{ABSTRAK}

Gulma merupakan tumbuhan yang dapat hidup pada areal pertanaman budidaya, untuk mengetahui jenis dari spesies gulma maka harus dilakukan kegiatan identifikasi. Identifikasi dilakukan dengan tujuan untuk melihat keanekaragaman suatu gulma dan gulma apa saja yang dominan pada areal pertanaman lada (Piper nigrum L.) di Kampung Sukan Tengah, Kecamatan Sambaliung, Kabupaten Berau, Provinsi Kalimantan Timur. Penelitian ini dilaksanakan pada tahun 2017. Metode penelitian yaitu dengan metode kuadrat, pengambilan sampel yaitu pada luasan $1 / 2$ ha lahan areal pertanaman lada dengan ukuran $1 \mathrm{~m}$ x $1 \mathrm{~m}$ sebanyak 20 petak contoh. Setelah didapatkan sampel gulma, selanjutnya yaitu mengidentifikasi gulma dan Summed Dominance Ratio. Hasil penelitian teridentifikasi ada 16 jenis gulma, dimana terdapat 5 spesies dari jenis gulma rerumputan, serta tercatat terdapat 11 spesies gulma berdaun lebar. Nilai Summed Dominance Ratio yang dominan yaitu Ageratum Conizoides sebesar $28.10 \%$.

Kata Kunci : Gulma, Identifikasi Gulma, Metode Kuadrat, keragaman gulma dan nilai SDR

\section{PENDAHULUAN}

Kampung Sukan Tengah merupakan wilayah yang berada di Kecamatan Sambaliung, Kabupaten Berau, Provinsi Kalimantan Timur. Berdasarkan pendataan pada tahun 2017, Kampung Sukan Tengah memiliki luasan lahan seluas $12.000 \mathrm{Ha}$, serta memiliki ketinggian 1.200 $\mathrm{m}$ dpl. Letak koordinat Bujur 2०5' 58,25" $117^{\circ} 37^{\prime} 24,86^{\prime \prime}$ BT, dan Koordinat Lintang $2^{\circ} 10^{\prime}$ $55,48^{\prime \prime}$ - 117³9' 15,24” LU.

Luas wilayah menurut penggunaannya terbagi menjadi enam, yaitu tanah sawah seluas $200 \mathrm{Ha}$, tanah kering seluas $1.117 \mathrm{Ha}$, tanah basah seluas $6.692 \mathrm{Ha}$, tanah perkebunan seluas 1.500 $\mathrm{Ha}$, tanah fasilitas umum seluas $58 \mathrm{Ha}$, dan tanah hutan seluas 2.700 Ha. Kampung Sukan Tengah memiliki jumlah bulan hujan selama 6 bulan, suhu rata-rata harian $30^{\circ} \mathrm{C}$, dan memiliki ketinggian tempat 35 meter dpl. Warna tanah di Kampung Sukan Tengah sebagian besar berwarna kuning hingga hitam, tekstur tanah pasir debu, dan memiliki lahan kritis seluas 200 Ha serta memiliki lahan terlantar seluas $3.000 \mathrm{Ha}$ (Profil Desa Kampung Sukan Tengah, 2017) . Salah satu komoditas yang di Kampung Sukan Tengah adalah tanaman Lada. Salah satu kendala yang terdapat di areal pertanaman lada adanya keberadaan organisme pengganggu tanaman.

Organisme pengganggu tanaman terdiri dari hama, penyakit dan gulma. Gulma dapat menyebabkan penurunan baik kualitas maupun kuantitas dari suatu tanaman. Kemampuan tanaman bersaing dengan gulma ditentukan oleh spesies gulma, kepadatan gulma, saat dan lama persaingan, cara budidaya dan varietas yang ditanam, serta tingkat kesuburan tanah. Perbedaan spesies akan menentukan kemampuan bersaing karena perbedaan sistem fotosintesis, kondisi perakaran dan keadaan morfologinya. Gulma merupakan tumbuhan yang tumbuh di tempat yang tidak dikehendaki oleh manusia atau tumbuhan yang kegunaannya belum diketahui (Tjitrosoedirdjo et al, 1984). Hadirnya gulma di perkebunan lada dapat menurunkan produksi 
karena gulma melakukan kompetisi dengan tanaman budidaya dalam memperebutkan air tanah, cahaya matahari, unsur hara, udara dan ruang tumbuh.

Maka dari itu, diperlukan pengelolaan dalam menanggulangi populasi gulma yang ada. Salah satu cara menanggulangi atau mengendalikan gulma tersebut yaitu dengan beberapa cara pengendalian baik secara mekanis, biologis, dan kimiawi. Namun sebelum mengetahui bagaimana cara pengendalian gulma yang tepat, terlebih dahulu harus memahami setiap spesies yang ada. Hal itu dikarenakan beda spesies beda cara penanggulangannya, sehingga identifikasi gulma sangat diperlukan agar gulma yang dikendalikan tepat sasaran.

Pada identifikasi gulma terdapat analisis vegetasi pengamatan yang dapat dilakukan pada areal pertanaman lada, untuk itu diperlukan petak contoh dalam mewakili areal tertentu. Salah satu cara menentukan distribusi petak contoh diantaranya sampling acak subyektif, sampling acak, sampling beraturan, dan sampling acak bertingkat. Namun metode dalam menentukan petak contoh yang digunakan adalah sampling beraturan dalam mengidentifikasi gulma pada areal pertanaman lada di Kampung Sukan Tengah Kecamatan Sambaliung Kabupaten Berau.

\section{BAHAN DAN METODE}

dipetakan selanjutnya dihitung jumlah gulmanya. Menurut Tjitrosoedirdjo, dkk, (1983) rumus kerapatan gulma sebagai berikut :

Kerapan mutlak suatu jenis = Jumlah semua individu jenis tertentu

Kerapatan mutlak suatu jenis

$$
=\frac{\text { Kerapatan mutlak jenis tertentu }}{\text { Jumlah kerapatan mutlak suatu jenis }} \times 100 \%
$$

b. Frekuensi Gulma

Frekuensi gulma yang terdapat pada petak contoh memuat jenis gulma tertentu dari sejumlah petak contoh dan dinyatakan dalam satuan persen (\%). Menurut Tjitrosoedirdjo, dkk, (1983) rumus frekuensi gulma sebagai beriku :

Frekuensi mutlak

Jumlah petak contoh yang memuat jenis tertentu

Frekuensi jumlah petak contoh
Frekuensi mutlak suatu jenis tertentu
$\frac{\text { Jumlah frekuensi mutlak semua jenis }}{\text { Jum }} \times 100 \%$
c. Indeks Nilai Penting Gulma
$\quad$ Indeks nilai penting gulma yang terdapat

pada petak contoh memuat penjumlahan antara kerapatan nisbi dengan frekuensi nisbi dalam persen $(100 \%)$. Rumusnya sebagai berikut :
Penelitian ini dilaksanakan pada tahun 2017 di Kampung Sukan Tengah Kecamatan Sambaliung Kabupaten Berau Provinsi Kalimantan Timur. Penelitian ini dilakukan pada salah satu kebun milik petani yang memiliki luasan kebun seluas $1 / 2$ ha. Alat dan bahan yang digunakan adalah gulma pada areal pertanaman lada (Piper nigrum L.) di Kampung Sukan Tengah Kecamatan Sambaliung Kabupaten Berau Provinsi Kalimantan Timur, dengan kuadran $1 \mathrm{~m}$ x $1 \mathrm{~m}$, tali rafia, gunting, pasak, meteran, alat tulis, plastik, kertas label.

Metode penelitian yaitu dengan metode kuadrat, pengambilan sampel yaitu pada luasan $1 / 2$ ha lahan areal pertanaman lada dengan ukuran $1 \mathrm{~m}$ x $1 \mathrm{~m}$ sebanyak 20 petak contoh.

Parameter pengamatan gulma yang diamati yaitu jumlah spesies gulma yang didapatkan dan nama-nama spesies dari gulma yang didapatkan. Selanjutnya untuk mendapatkan data dari parameter yang diambil maka dapat diolah menggunakan beberapa rumus, rumus tersebut berupa nilai kerapatan gulma, frekuensi gulma, nilai penting dan Summed Dominance Ratio (SDR) sebagai berikut.

a. Kerapatan Gulma

Kerapatan berkaitan dengan populasi tumbuhan pada tiap petak contoh. Gulma tersebut dipilih berdasarkan jenisnya yang ada

INP = Kerapatan nisbi suatu jenis tertentu + Frekuensi nisbi suatu jenis tertentu

d. $\quad$ Summed Dominance Ratio (SDR) Gulma Summed Dominance Ratio (SDR) gulma pada petak contoh memuat indeks nilai penting dibagi dua. Nilai SDR dapat dihitung dengan menggunakan rumus sebagai berikut :

Summed Dominance Ratio (SDR) $=\frac{\text { Indeks nilai penting }}{2}$

\section{HASIL DAN PEMBAHASAN}

Hasil pengamatan gulma pada areal pertanaman lada di Kampung Sukan Tengah Kecamatan Sambaliung Kabupaten Berau Provinsi Kalimantan Timur menunjukkan bahwa jenis gulma yang teridentifikasi tercatat ada 16 jenis gulma pada Tabel 1. Gulma Sampling Beraturan. Tabel 2 menunjukkan bahwa spesies gulma yang termasuk ke dalam gulma rumput terdapat 5 spesies, yaitu : Digitaria sanguinalis, Paspalum conjugatum, Eleusin indica, Eleusin sp., dan Ottochloa nodosa. Serta tercatat terdapat 11 spesies gulma berdaun lebar, yaitu : Euphorbia 
hirta, Borreria latifolia, Cleome rutidospemae, Brassica compestris, Melastoma malabatricum, Ageratum conizoides, Commelina nudiflora L.,

Tabel 1. Identifikasi Gulma pada Areal Pertanaman Lada (Piper nigrum L.) Sampling Beraturan

\begin{tabular}{lll}
\hline No & Nama Gulma & Nama Lokal \\
\hline 1 & Euphorbia hirta & Patikan Kebo \\
2 & Digitaria sanguinalis & Rumput Belalang \\
3 & Paspalum conjugatum & Rumput Pait \\
4 & Borreria latifolia & Kentangan \\
5 & Cleome rutidosperma & Maman Ungu \\
6 & Brassica campestris & Mustard Liar \\
7 & Eleusin indica & Belulangan \\
8 & Melastoma malabatricum & Senduduk \\
9 & Ageratum Conizoides & Wedusan/Babandotan \\
10 & Commelina nudiflora L. & Aur-aur \\
11 & Eleusin sp. & Rumput Belulangan \\
12 & Phylanthus urinaria & Meniran \\
13 & Ottochloa nodosa & Rumput Sarang Buaya \\
14 & Coleus rotundifolius & Kentang Hitam \\
15 & Asystasia intrusa & Rumput Ganda Rusa \\
16 & Chromolaena odorata & Kirinyuh \\
\hline
\end{tabular}

Berdasarkan pada Tabel 2. Nilai Summed Dominance Ratio (SDR) Gulma pada Areal Pertanaman Lada (Piper nigrum L.) Sampling Beraturan, nilai SDR mencapai $100 \%$. Gulma yang memiliki nilai SDR tertinggi berasal dari golongan gulma rerumputan, yaitu Ageratum

Conizoides dengan persentase sebesar $28.10 \%$. Sedangkan untuk nilai SDR terkecil berasal dari golongan gulma berdaun lebar, yaitu : Melastoma malabraticum, Asystasia intrusa dan Chromolaena odorata yang memilki persentase sebesar $0,69 \%$.

Tabel 2. Nilai Summed Dominance Ratio (SDR) Gulma pada Areal Pertanaman Lada (Piper nigrum L.) Sampling Beraturan

\begin{tabular}{llc}
\hline No & Nama Gulma & Summed Dominance Ratio (SDR) \\
\hline 1 & Euphorbia hirta & 1.42 \\
2 & Digitaria sanguinalis & 25.08 \\
3 & Paspalum conjugatum & 1.39 \\
4 & Borreria latifolia & 1.85 \\
5 & Cleome rutidosperma & 19.09 \\
6 & Brassica campestris & 0.73 \\
7 & Eleusin indica & 4.33 \\
8 & Melastoma malabatricum & 0.69 \\
9 & Ageratum Conizoides & 28.10 \\
10 & Commelina nudiflora L. & 0.80 \\
11 & Eleusin sp. & 3.24 \\
12 & Phylanthus urinaria & 5.87 \\
13 & Ottochloa nodosa & 2.22 \\
14 & Coleus rotundofolius & 3.79 \\
15 & Asystasia intrusa & 0.69 \\
16 & Chromolaena odorata & 0.69 \\
\hline Total & & $\mathbf{1 0 0 \%}$ \\
\hline
\end{tabular}

Keragaman gulma sangat penting untuk dipelajari, hal itu dikarenakan untuk mengetahui komposisi dan struktur gulma yang terdapat pada areal pertanaman lada dan dapat menentukan pengendalian yang tepat. Keragaman gulma sangat dipengaruhi oleh keadaan kondisi 
lingkungan sekitar (Perdana et al, 2013). Banyak faktor yang mempengaruhi keragaman suatu gulma pada setiap lokasi gulma yang diamati, seperti cahaya, unsur hara, pengolahan tanah, cara budidaya tanaman, serta jarak tanam atau kerapatan tanaman yang digunakan berbeda serta usia tanaman lada tersebut.

Identifikasi gulma yang dilakukan pada masing-masing petak contoh yaitu dengan cara melihat secara visual bentuk morfologi gulma tersebut, kemudian dicocokkan dengan pustaka (Caton et al, 2011). Selanjutnya yaitu mengelompokkan gulma berdasarkan spesies dan kemudian dihitung jumlahnya apabila spesiesnya telah diketahui. Identifikasi berfungsi dalam memperoleh data keragaman dan dominasi jenis gulma pada areal pertanaman lada secara keseluruhan namun dengan beberapa sampel yang mewakili.

Gulma yang ditemukan di areal pertanaman lada sangat beragam mulai dari golongan gulma rerumputan, gulma berdaun lebar, dan gulma teki. Pada pengambilan petak contoh gulma dilakukan dengan metode sampling beraturan. Pengambilan petak contoh sampling beraturan dimaksudkan untuk mengetahui identifikasi gulma pada areal pertanaman lada

Jumlah jenis gulma terbanyak dari hasil identifikasi adalah jenis gulma berdaun lebar, yaitu sebanyak 11 jenis, dimungkinkan karena lahan yang cocok untuk pertumbuhan gulma jenis ini. Menurut Tjitrosoepomo et al. (1987), tanah yang sedikit lembab merupakan tempat yang disukai oleh golongan berdaun lebar, sedangkan gulma jenis teki dan rumput lebih menyukai lahan terbuka. Di sekitar areal pertanaman jeruk terdapat tanaman penaung dari gamal dan beberapa pepohonan hutan.

Pengambilan petak contoh pada areal pertanaman lada seluas $1 / 2$ ha atau $50 \mathrm{~m} \times 100 \mathrm{~m}$ yaitu dengan menggunakan metode pengambilan petak contoh sampling beraturan. Petak contoh yang digunakan yaitu dengan ukuran $1 \mathrm{~m} \times 1 \mathrm{~m}$, dengan jarak antar petak yaitu seluas $5 \mathrm{~m}$ x $20 \mathrm{~m}$. Sampel yang diambil pada petak contoh sampling beraturan sebanyak 20 sampel untuk mewakili dari keseluruhan gulma yang ada.

Dapat dilihat pada Tabel 1, jenis gulma yang ditemukan sangat beragam. Hal ini menunjukkan bahwa pada areal pertanaman lada merupakan tempat yang cocok bagi pertumbuhan gulma tersebut. Perbedaan pengelolaan tanaman dapat menyebabkan perbedaan jenis gulma, pengelolaan tersebut dapat berupa pengaturan air dan pemupukan serta adanya perbedaan morfologi dan karakter yang menyusun tanaman tersebut serta dapat merubah mikroklimat sehingga menimbulkan respons yang berbeda pada setiap jenis gulma (Mercado 1979).

Berdasarkan metode pengambilan petak contoh untuk identifikasi gulma pada sampling beraturan harus menentukan terlebih dahulu jumlah petak contoh yang akan mewakili dalam luasan suatu wilayah lahan dan jarak antar petak contoh serta ukuran petak contohnya. Sehingga gulma yang didapatkan pada petak contoh ada yang banyak populasinya dan sedikit populasinya tergantung pada kondisi lahan yang ada.

Tanah yang berada di sekitar areal pertanaman lada memiliki tekstur pasir debu, sehingga pemencaran gulma sangat besar. Berdasarkan pada kondisi tanah yang ada pada areal pertanaman lada sangat cocok bagi pertumbuhan gulma, karena tanah memilki struktur yang tidak begitu padat, sehingga mempercepat bagi pertumbuhan gulma.

Walaupun pada kenyataannya gulma banyak memberikan dampak negatif pada tanaman budidaya. Namun terdapat beberapa jenis gulma yang tumbuh pada areal pertanaman lada yang memiliki potensi kemanfaatan baik untuk keperluan manusia dan sebagainya. Manfaat gulma sendiri selain sebagai pakan, yaitu sebagai bahan obat tradisional. Informasi akan potensi pemanfaatan gulma penting untuk dipelajari untuk mempertimbangkan dalam pemilihan teknik pengendaliannya.

\section{KESIMPULAN}

Identifikasi gulma pada areal pertanaman lada pada sampling beraturan didapatkan nilai SDR tertinggi berasal dari golongan gulma daun lebar yaitu Ageratum Conizoides dengan persentase sebesar $28.10 \%$. Sedangkan untuk nilai SDR terkecil berasal dari golongan gulma berdaun lebar, yaitu : Melastoma malabraticum, Asystasia intrusa dan Chromolaena odorata yang memilki persentase sebesar $0,69 \%$.

\section{DAFTAR PUSTAKA}

Caton, B. P., M. Mortimer, J. E. Hill, and D. E. Johnson. 2011. Panduan Lapang Praktis Gulma Padi Asia. International Rice Research Institute. Makati City, Philippine.

Feira, A. R., Z. Arifin dan Sunarti. 2014. Posisi Daya Saing dan Spesialisasi Perdagangan Lada Indonesia dalam Menghadapi Globalisasi (Studi Pada Ekspor Lada Indonesia Tahun 2009- 
2013). Jurnal Administrasi Bisnis (JAB). 27 (2) : $1-7$.

Mercado, B. L. 1979. Introduction to Weed Science. Southeast Asia Regional Centre for Graduate Study and Research in Agriculture. p 37-69.

Perdana, E. O., Chairul, dan Z. Syam. 2013. Analisis Vegetasi Gulma Pada Tanaman Buah Naga (Hylecereus polyrhizus L.) Di Kecamatan Batang Anai, Kabupaten Padang Pariaman, Sumatera Barat. Jurnal Biologi Universitas Andalas. 2 (4) : 242 - 248.

Profil Desa. 2017. Profil Kampung. Kampung Sukan Tengah. Kecamatan Sambaliung. Kabupaten Berau. Provinsi Kalimantan Timur.

Tjitrosoedirdjo, S., I.H. Utomo, dan J. Witroatmodjo. 1983. Pengelolaan Gulma di Perkebunan. Gramedia. Jakarta.

Tjitrosoepomo, G.M. Soerjani, dan Kostermans. 1987. Weeds of rice in Indonesian. Balai Pustaka. Jakarta. 